\title{
Review of the chemistry and pharmacology of 7-Methyljugulone
}

\author{
Armelle T. Mbaveng*, Victor Kuete
}

Department of Biochemistry, Faculty of science, University of Dschang, Cameroon.

\begin{abstract}
Background: Naphthoquinone is a class of phenolic compounds derived from naphthalene. 7-Methyljuglone (7-MJ) is a naphthoquinone also known as ramentaceone or 6-Methyl-8-hydroxy-1,4-naphthoquinone or 5-Hydroxy-7-methyl-1,4naphthoquinone or 7-Methyl-5-hydroxy-1,4-naphthoquinone or 5-Hydroxy-7-methyl-,1,4-naphtoquinone or 7-Methyl-5hydroxynaphthalene-1,4-dione. This compound is a biologically active naphtoquinone, with a molecular weight of $188 \mathrm{~g} /$ mol mostly isolated in the genus Diospyros and Euclea.

Objectives: This review was aimed at providing available chemically and pharmacological data on 7-MJ.

Methods: The chemical and pharmacological data were retrieved from the well-known scientific websites such as Pubmed, Google Scholar, Reaxys, Scirus, Scopus, Sciencedirect, Web-of-knowledge and Scifinder.

Results: 7-MJ was reported to have a variety of pharmacological activities such as antibacterial, antifungal, anticancer, antitubercular, anti-inflammatory and antiviral activities. The hemi-synthesis of the compound have been described.

Conclusions: The present review pooled out together the knowledge on 7-MJ, and can serve as the start point for future research and valorization accomplishments.
\end{abstract}

Key words: 7-methyljugulone; biosynthesis; in vitro synthesis; pharmacology

African Health Sciences 2014;14(1): 201-205 http://dx.doi.org/10.4314/ahs.v14i1.31

\section{Introduction}

Naphthoquinone is a class of phenolic compounds derived from naphthalene occurring to some extent in fungi and are extremely common in higher plants and contain the naphthalene nucleus with two carbonyl groups on one nucleus usually at the ortho or para position (bicyclic). Naphthoquinones are widely distributed in plants, fungi and some animals and many were found to exhibit interesting range of pharmacological properties such as antibacterial ${ }^{1,2}$, antiviral $^{3}$, trypanocidal ${ }^{4}$, anticancer ${ }^{5}$, antimalarial ${ }^{6,7}$ and antifungal ${ }^{8}$ activities. Other quinone-related scaffolds such as 2-H-pyran-3(6H)-one derivatives ${ }^{8}$ and 2,3dideoxyhexenopyranosides ${ }^{9}$ are also known for their biological activities against Staphylococcus species and Mycobacterium tuberculosis. Interestingly, 7-MJ, a naphthoquinone exhibits most of these activities. Therefore, we undertook the present review to bring out pharmacological knowledge on 7-MJ. We also discussed herein the biosynthesis and the in vitro synthesis of this compound.

\section{Correspondence author:}

Armelle T. Mbaveng

Department of Biochemistry, Faculty of science, University of Dschang, Cameroon

P.O. Box 67 Dschang-Cameroon

Email:armkuete@yahoo.fr

\section{Methods}

The chemical and pharmacological data were collected from the well-known scientific websites such as Pubmed, Google Scholar, Scirus, Scopus, Sciencedirect, Reaxys, Web-of-knowledge and Scifinder. The chemical names, 7-methyjulglone, ramentaceone or 6-Methyl-8-hydroxy1,4-naphthoquinone or 5-Hydroxy-7-methyl-1,4-naphthoquinone or 7-Methyl-5-hydroxy-1,4-naphthoquinone or 5-Hydroxy-7-methyll-,1,4-naphtoquinoneor 7-Methyl-5-hydroxynaphthalene-1,4-dione were used as key word in the above websites and all relevant research papers were retrieved. The collected documents served as necessary tools and were analyzed for data collection.

\section{Results}

The naphthoguinone 7-MG has been isolated from different parts of the plants of the family Ebenaceae; This includes the bark of Diospyros maritima ${ }^{10}$, the twigs of Diospyros lycioides Desf. ${ }^{11}$, the roots of Diospyros lotus L. ${ }^{12}$, Euclea natalensisA.DC. ${ }^{13}$, Euclea undulata ${ }^{14}$ and Diospyros virginiana. ${ }^{15}$ 7-MG (Fig. 1) appeared as an orange needles [m.p. $150-152^{\circ} \mathrm{C},{ }^{11}$ or $155^{\circ} \mathrm{C}^{16}$ or $156^{\circ} \mathrm{C}$, or yellow needles; mp. $126^{\circ} \mathrm{C}$; density $1.371 \mathrm{~g} /$ $\mathrm{cm}^{3}$; boiling point: $427.2^{\circ} \mathrm{C}$ at $760 \mathrm{mmHg}$; refractive index: 1.642]. $\operatorname{IR}\left(\mathrm{KBr}, \mathrm{cm}^{-1}\right): 1670,1645(\mathrm{C}=\mathrm{O}) ; \delta_{\mathrm{H}}$ (CDCl3, $200 \mathrm{MHz}) ; 11.84$ (1H, s, 5-OH), $7.42(1 \mathrm{H}, \mathrm{s}$, H-8), 7.06 (1H, s, H-6), 6.89 (2H, s, H-2, H-3), 2.41 (3H, s, CH3); found: (EI) 188.0475, $\mathrm{C}_{11} \mathrm{H}_{8} \mathrm{O}_{3}$ requires $188.0473 .{ }^{17}$ 
<smiles>Cc1cc(O)c2c(c1)C(=O)C=CC2=O</smiles>

Fig.1. Chemical structure of 7-methyljuglone (7-MJ)

\section{Biosynthesis and in vitro synthesis}

It has been shown that higher plants have developed at least three separate pathways for the synthesis of the naphthoquinone carbon skeleton, including the shikimate, the homogentisate and the polyacetatemalonate pathways. The two main ways of naphthoquinones biosynthesis in higher plants include direct incorporation of shikimate ${ }^{17}$ or the homogentisic acid pathway involving the condensation of mevalonic acid and most probably toluhydroquinone ${ }^{17}$. It was demonstrated that 2-Methyl-juglone (plumbagin) by its striking structural similarity with juglone and menadion was expected to be formed via the shikimate pathway, by C-methylation of Juglone in the 2 position $^{18}$. According to Durand and Zenk ${ }^{19}$ plumbagin and $7-\mathrm{MJ}$ are the first napthoquinones in higher plants shown to be formed according to the acetate pathway which has long been known for the formation of naphthoquinones in fungi ${ }^{20}$. An hexaacetyl chain leads to the formation of these naphthalenes ${ }^{19}$.

The synthesis of 7-MJ was realized by Mahapatra ${ }^{21}$ as follows: A mixture of anhydrous $\mathrm{AlCl}_{3}(40 \mathrm{~g}, 300$ $\mathrm{mmol})$ and $\mathrm{NaCl}(8 \mathrm{~g}, 137 \mathrm{mmol})$ were heated to $180^{\circ} \mathrm{C}$. A mixture of appropriate 4-halo-3-methyl phenol (10.7 mmol) or 4-halo-2-methyl phenol and maleicanhydride (4 g, $40.8 \mathrm{mmol}$ ) was added to the above melt with vigorous stirring for $2 \mathrm{~min}$, and then poured into a mixture of ice and $12 \mathrm{M} \mathrm{HCl}$. The mixture was kept for $30 \mathrm{~min}$, and the precipitate was filtered and dried at room temperature overnight. The residue obtained was powdered and extracted with n-hexane with vigorous stirring at $50^{\circ} \mathrm{C}$. The extract was concentrated under reduced pressure and crystallized from chloroform to afford the halogenated products 2-5. A solution of 3 (200 mg, $0.90 \mathrm{mmol})$ in THF $(20 \mathrm{~mL})$ was added dropwise to a solution of $\mathrm{SnCl} 2(1.0 \mathrm{~g}, 51 \mathrm{mmol})$ in $4 \mathrm{M} \mathrm{HCl}$ $(70 \mathrm{~mL})$ and THF $(20 \mathrm{~mL})$ at $60{ }^{\circ} \mathrm{C}$ and stirred for $3 \mathrm{~h}$. It was then cooled and filtered into a solution of $\mathrm{FeCl}$. The resulting precipitate was filtered and dried to afford 7-MJ (Fig. 2).

Fig.2. Synthesis of 7-methyljugulone. Reagents and conditions: (i) maleic anhydride, $\mathrm{AlCl}_{3}, \mathrm{NaCl}, 180^{\circ} \mathrm{C}, 2$ min; (ii) $\mathrm{SnCl}_{2}, 4 \mathrm{M} \mathrm{HCl} / \mathrm{THF}, 60^{\circ} \mathrm{C}, 2-4 \mathrm{~h}^{17}$.<smiles>[R]c1ccc(O)c([R])c1[R]</smiles>

2-5

$\begin{array}{cc}\text { Naphthoquinone } & \text { X } \\ 2 & \mathrm{~F} \\ 3 & \mathrm{Cl} \\ 4 & \mathrm{Br} \\ 5 & \mathrm{Cl} \\ 6 & \mathrm{H} \\ 1(7-\mathrm{MJ}) & \mathrm{H}\end{array}$

The antifungal activities of 7-MJ were reported against Cryptococcus neoformans $[50 \%$ inhibition of growth concentration $\left(\mathrm{GI}_{50}\right)$ of $0.3 \mu \mathrm{g} / \mathrm{mL}$ and a Minimal Inhibitory Concentration (MIC) of $1 \mu \mathrm{g} / \mathrm{mL}$, Candida albicans $\left(\mathrm{GI}_{50}: 0.3 \mu \mathrm{g} / \mathrm{mL}\right.$; MIC: $20 \mu \mathrm{g} / \mathrm{mL}$ ),

$\begin{array}{ccc}\text { R1 } & \text { R2 } & \text { R3 } \\ \mathrm{Me} & \mathrm{H} & \mathrm{OH} \\ \mathrm{Me} & \mathrm{H} & \mathrm{OH} \\ \mathrm{Me} & \mathrm{H} & \mathrm{OH} \\ \mathrm{H} & \mathrm{Me} & \mathrm{OH} \\ \mathrm{H} & \mathrm{Me} & \mathrm{OH} \\ \mathrm{Me} & \mathrm{H} & \mathrm{OH}\end{array}$

Saccharomyces cerevisiae $\left(\mathrm{GI}_{50}: 0.3 \mu \mathrm{g} / \mathrm{mL}\right.$; MIC: $1 \mu \mathrm{g} /$ $\mathrm{mL}$ ) and Aspergillus niger $\left(\mathrm{GI}_{50}: 5 \mu \mathrm{g} / \mathrm{mL}\right.$; MIC: $300 \mu \mathrm{g} /$ $\mathrm{mL}) .{ }^{10} \quad 7-\mathrm{MJ}$ also displayed antifungal activities against Phomopsis obscurans [inhibition percentage (IP) of 97\%] and Phomopsis viticola (IP of $53.4-54.3 \%$ ) at 
$30 \mu \mathrm{M} \cdot{ }^{15}$

7-MJ also demonstrated inhibitory activities against the Gram-positive oral streptococci, Streptococcus mutans (MIC of $156 \mu \mathrm{g} / \mathrm{mL}$ ) and S. sanguis (MIC: $78 \mu \mathrm{g} / \mathrm{mL}$ ) as well as against the Gram-negative anaerobic rods Prevotella gingivalis (MIC: $39 \mu \mathrm{g} / \mathrm{mL}$ ) and P. intermedia (MIC: $78 \mu \mathrm{g} / \mathrm{mL}$ ) frequently associated with human peritonitis known as gum disease. ${ }^{11}$ The antibacterial activity of this compound was also reported against $\mathrm{M}$. luteus $\left(\mathrm{GI}_{50}: 20 \mu \mathrm{g} / \mathrm{mL}\right.$; MIC: $\left.1000 \mu \mathrm{g} / \mathrm{mL}\right){ }^{10}$

7-MJ showed an exceptional antitubercular inhibitory effects against Mycobacterium tuberculosis $\mathrm{H} 37 \mathrm{Rv}$ with a MIC value of $0.5 \mu \mathrm{g} / \mathrm{mL}$ combined to a very good selectivity index of 30.22 on normal vero cells. ${ }^{21}$ This compound was found to react as potent subversive substrate for the NADPH-dependent enzyme mycothiol disulfide reductase of M. tuberculosis, which is one of several potential biological targets for it anti-mycobacterial activity ${ }^{17}$. In fact, M. tuberculosis lacks glutathione, instead it maintains millimolar concentrations of the structurally distinct low molecular weight thiol mycothiol (MSH) ${ }^{17}$ Analogous to glutathione, MSH plays an important role in oxidative stress management and is oxidized to the symmetrical disulfide (MSSM) in the process. The NADPHdependent enzyme mycothiol disulfide reductase $(\mathrm{Mtr})^{22}$ helps to maintain an intracellular reducing environment by reducing MSSM back to MSH. MSH is essential for the growth of $\mathrm{M}$. tuberculosis ${ }^{23}$ and MSH-deficient mycobacteria exhibit increased sensitivity to oxidative stress making this redox pathway a potential biological target for novel antitubercular chemotherapies. ${ }^{21}$ 7-MJ also showed a very good antimycobacterial activity on other mycobacteria, with MIC values as low as $1.55 \mu \mathrm{g} /$ $\mathrm{mL}$ against $\mathrm{M}$. bovis, $1.57 \mu \mathrm{g} / \mathrm{mL}$ against $\mathrm{M}$. smegmatis and $1.55 \mu \mathrm{g} / \mathrm{mL}$ on $\mathrm{M}$. fortuitum. ${ }^{14}$ A $50 \%$ inhibition of growth concentration was also reported to be $5 \mu \mathrm{g} /$ $\mathrm{mL}$ against $\mathrm{M}$. avium. ${ }^{10}$

7-MJ displayed antiviral activities through the inhibition of recombinant reverse transcriptase of HIV-1 with 80 to $100 \%$ inhibition at the concentration ranges of 12.5 to $100 \mu \mathrm{g} / \mathrm{mL} .{ }^{24}$ This phytochemical also inhibited the human rhinovirus $3 \mathrm{C}$ protease with an $\mathrm{IC}_{50}$ value of 6.4 $\mu \mathrm{M}^{25}$

The cytotoxicity of 7-MJ was reported on several cancer cell lines including human oral epidermoid carcinoma
$\left[\mathrm{KB}\left(\mathrm{IC}_{50}\right.\right.$ value of $\left.\left.4.1 \mu \mathrm{M}\right)\right]$, the human lung cancer cells [Lu1 $\left.\left(\mathrm{IC}_{50}: 13.2 \mu \mathrm{M}\right)\right]$ and hormone-dependent human prostate cancer cells $[\mathrm{LNCaP}]\left(\mathrm{IC}_{50}: 3.7 \mu \mathrm{M}\right) .{ }^{10}$ Though this compound was less toxic against the normal monkey kidney vero cells ${ }^{21}$, its toxicity toward the Umbilical Vein Endothelial Cells (HUVEC) was rather found to be higher $\left(\mathrm{IC}_{50}: 5.7 \mu \mathrm{M}\right)$ clearly indicating that possible chemotherapy involving pregnant women should be taken with caution. At $10 \mu \mathrm{M}, 7-\mathrm{MJ}$ induced apoptosis against leukemia HL60 cells with the percentage of Sub-G1 phase ranged from $10.3-27.5 \%$ whilst the $\mathrm{IC}_{50}$ value of $8.75 \mu \mathrm{M}$ was reported on this cell line. ${ }^{26}$

\section{Discussion}

7-MJ was isolated mostly in the family Moraceae. especially in the genus Diospyros and Euclea. The occurrence of naphthoquinones in the two genera has been documented ${ }^{10-15}$. Its partial synthesis has also been described $^{21}$, suggesting that the compounds can easily be available for any in vivo and possible clinical studies. Phytochemicals are routinely classified as antimicrobials on the basis of susceptibility tests that produce MIC in the range of 100 to $1000 \mathrm{mg} / \mathrm{mL}^{27}$. Activity is considered to be significant if MIC values are below $10 \mu \mathrm{g} / \mathrm{mL}$ for pure compound, moderate when $10<\mathrm{MIC}<100$ $\mu \mathrm{g} / \mathrm{mL}$ and low when the MIC values is above 100 $\mu \mathrm{g} / \mathrm{mL}^{28,29}$. On this basis, 7-MJ can be considered as significantly effective antimicrobial compound against Saccharomyces cerevisiae (MIC: $1 \mu \mathrm{g} / \mathrm{mL})^{10}$, M. bovis $(1.55 \mu \mathrm{g} / \mathrm{mL})$, M. smegmatis $(1.57 \mu \mathrm{g} / \mathrm{mL})$ and $\mathrm{M}$. fortuitum $(1.55 \mu \mathrm{g} / \mathrm{mL}){ }^{14}$. This clearly shows that this compounds can be explored more as potential drug against some pathogenic fungi and bacteria. In the US NCI screening program, a compound is generally considered to have in vitro cytotoxic activity, if the $\mathrm{IC}_{50}$ value following incubation between 48 and $72 \mathrm{~h}$, is less than $4 \mu \mathrm{g} / \mathrm{ml}$ or $10 \mu \mathrm{M}^{30}$.

On this basis, 7-MJ can also be considered as a good cytotoxic compound against several cancer cell lines such as $\mathrm{KB}$, Lu1 and $\mathrm{LNCaP}^{10}$. Its selectivity toward cancer cells as compared with the normal vero monkey kidney cells ${ }^{17}$ suggests that this compound is relatively safe for a potential anticancer treatment. Nevertheless, its toxicity toward the HUVEC indicated that caution should be taken when a potential treatment involve a pregnant women.

\section{Conclusion}

The present review obviously showed that 7-MJ could 
move forward into in vivo studies, in regards to its enormous pharmacological activities. Also, the study of the possible drug-drug interaction of $7-\mathrm{MJ}$ is to be investigated. However, 7-MJ displayed high toxicity in HUVEC cells, clearly indicating that caution should be taken for any treatment involving pregnant women. The easy way of the in vitro chemical synthesis of 7-MJ ensure the availability of the compound for necessary future studies. Finally, the present work can served as a the future starting point for the developments of pharmaceutical from this potentially potent biological molecule.

\section{Acknowledgment}

The authors are thankful to Mr. Seydina Diene (University of Marseille, France); Mr. Arnaud T. D. Tchatchou of the University of the Witwatersrand, Johannesburg and Louis P. Sandjo of the University of Mainz-Germany for their fruitful contribution in the literature search.

\section{References}

1. Roushdi IM, Ibrahim ESA, Habib NS. Synthesis of 1.4-naphthoquinones-4-aryl(aroyl)hydrazones of potential antimicrobial activity. Pharmazie 1976, 31: 856859.

2. Osman SAA, Abdalla AA, Alaib MOJ. Synthesis of sulfanilamido-naphthoquinones as potential antituberculous agents. Pharm Sci 1983, 72:68-71.

3. Brinkworth RI, Fairlie DP. Hydroxyquinones are competitive non-peptide inhibitors of HIV-1 proteinase. Biochim Biophys Acta 1995, 1253: 5-8.

4. Salmon-Chemin L, Buisine E, Yardley V, Kohler S, Debreu MA, Landry V, Sergheraert C, Croft SL, KrauthSiegel RL, Davioud-Charvet E. 2- and 3-substituted 1,4naphthoquinone derivatives as subversive substrates of trypanothione reductase and lipoamide dehydrogenase from Trypanosoma cruzi: synthesis and correlation between redox cycling activities and in vitro cytotoxicity. J Med Chem 2001, 44: 548-465.

5. Hazra B, Sur P, Roy DK, Sur B, Banerjee A. Biological activity of diospyrin towards Ehrlich ascites carcinoma in Swiss A mice. Planta Med 1984, 51: 295-297

6. Perry NB, Blunt JW, Munro MH. A cytotoxic and antifungal 1,4-naphthoquinone and related compounds from a New Zealand brown algae, Landsburgia quercifolia. J Nat Prod 1991, 54: 978-985.

7. Yardley V, Snowdon D, Croft S, Hazra B. In vitro activity of diospyrin and Derivatives against Leishmania donovani, Trypanosoma cruzi and Trypanosoma brucei brucei. Phytother Res 1996, 10: 559-562.
8. Georgiadis MP, Couladouros EA, Delitheos AKJ. Synthesis and antimicrobial properties of $2 \mathrm{H}$-pyran$3(6 \mathrm{H})$-one derivatives and related compounds. Pharm Sci 1992, 81: 1126-1131.

9. Saquib M, Gupta MK, Sagar R, Prabhakar YS, Shaw AK, Kumar R, Maulik PR, Gaikwad AN, Sinha S, Srivastava AK, Chaturvedi V, Srivastava R, Srivastava BS. C-3 alkyl/arylalkyl-2,3-dideoxy hex-2-enopyranosides as antitubercular agents: synthesis, biological evaluation, and QSAR study. J Med Chem 2007, 50: 2942-2950.

10. Gu JQ, Graf TN, Lee D, Chai HB, Mi Q, Kardono LB, Setyowati FM, Ismail R, Riswan S, Farnsworth NR, Cordell GA, Pezzuto JM, Swanson SM, Kroll DJ, Falkinham JO 3rd, Wall ME, Wani MC, Kinghorn AD, Oberlies NH. Cytotoxic and antimicrobial constituents of the bark of Diospyros maritima collected in two geographical locations in Indonesia. J Nat Prod 2004, 67: 1156-1161.

11. Cai L, Wei GX, van der Bijl P, Wu CD. Namibian chewing stick, Diospyros lycioides, contains antibacterial compounds against oral pathogens. J Agric Food Chem 2000, 48: 909-914.

12. Yoshihira K, Tezuka M, Natori S. Naphthoquinone derrivatives from the Ebenaceae. II. Isodiospyrin, bisisodiospyrin, and mamegakinone from Diospyros lotus L. and D. morrisiana Hance. Chem Pharm Bull 1971, 19: 2308-2313.

13. Lall N, Meyer JJM, Wang Y, Bapela NB, van Rensburg CEJ, Fourie B, Franzblau SG. Characterization of intracellular activity of antitubercular constituents the roots of Euclea natalensis. Pharm Biol 2005, 43: 353357.

14. McGaw LJ, Lall N, Hlokwe TM, Michel AL, Meyer JJ, Eloff JN. Purified compounds and extracts from Euclea species with antimycobacterial activity against Mycobacterium bovis and fast-growing mycobacteria. Biol Pharm Bull 2008, 31: 1429-1433.

15. Wang X, Habib E, León F, Radwan MM, Tabanca N, Gao J, Wedge DE, Cutler SJ. Antifungal metabolites from the roots of Diospyros virginiana by overpressure layer chromatography. Chem Biodivers 2011, 8: 2331 2340.

16. Hedin PA, Collum DH, Langhans VE, Graves CH. Distribution of juglone and related compounds in pecan and their effect on Fusicladium effusum. J Agric Food Chem 1980, 28: 340-344.

17. Zenk MH, Leistner E. Biosynthesis of quinones. Lloydia 1968, 31: 275-292.

18. Teuscher E. "Pharmakognosie" part II, Akademie Verlag, Berlin, 1970, p.245.

19. Durand R, Zenk MH. Biosynthesis of plumbagin 
(5-hydroxy-2-methyl-1,4-naphthoquinone) via the acetate pathway in higher plants. Tetrahedron Lett 1971, 32: 3009-3012.

20. Thomson RH. „Naturally Occurring Quinones“, Academic Press, London and New York, 1971, p. 1315.

21. Mahapatra A, Mativandlela SP, Binneman B, Fourie PB, Hamilton CJ, Meyer JJ, van der Kooy F, Houghton P, Lall N. Activity of 7-methyljuglone derivatives against Mycobacterium tuberculosis and as subversive substrates for mycothiol disulfide reductase. Bioorg Med Chem 2007, 15: 7638-7646.

22. Patel MP, Blanchard JS. Expression, purification, and characterization of Mycobacterium tuberculosis mycothione reductase. Biochemistry 1999, 38: 1182711833.

23. Sareen D, Newton GL, Fahey RC, Buchmeier NA. Mycothiol is essential for growth of Mycobacterium tuberculosis Erdman. J Bacteriol 2003, 185: 6736-6740.

24. Mahapatra A, Tshikalange TE, Meyer JJM, Lall N. Synthesis and HIV-1 reverse transcriptase inhibition activity of 1,4-naphthoquinone derivatives. Chem Nat Comp 2012, 47: 883-887.

25. Singh SB, Graham PL, Reamer RA, Cordingley MG.
Discovery, total synthesis, HRV 3C-protease inhibitory activity, and structure-activity relationships of 2-methoxystypandrone and its analogues. Bioorg Med Chem Lett 2001, 11: 3143-3146.

26. Kawiak A, Zawacka-Pankau J, Wasilewska A, Stasilojc G, Bigda J, Lojkowska E. Induction of apoptosis in HL-60 cells through the ROS-mediated mitochondrial pathway by ramentaceone from Drosera aliciae. J Nat Prod 2012, 75:9-14.

27. Simões M, Bennett RN, Rosa EA. Understanding antimicrobial activities of phytochemicals against multidrug resistant bacteria and biofilms. Nat Prod Rep 2009, 26:746-757.

28. Kuete V. Potential of Cameroonian plants and derived products against microbial infections: a review. Planta Med 2010, 76:1479-1491.

29. Kuete V, Efferth T: Cameroonian medicinal plants: pharmacology and derived natural products. Front Pharmacol 2010, 1:123.

30. Kuete, V., Ngameni, B., Wiench, B., Krusche, B., Horwedel, C., Ngadjui, B.T., Efferth, T. Cytotoxicity and mode of action of four naturally occuring flavonoids from the genus Dorstenia: gancaonin Q, 4-hydroxylonchocarpin, 6-prenylapigenin, and 6,8-diprenyleriodictyol. Planta Med 2011: 77, 1984-1989. 